\title{
AKUNTABILITAS KINERJA INSTANSI PEMERINTAH : APAKAH DIPENGARUHI KOMPETENSI APARATUR, TEKHNOLOGI INFORMASI, PENGENDALIAN AKUNTANSI, DAN SISTEM PELAPORAN?
}

\author{
${\text { Gebyvia Septiyani }{ }^{*} \text {, Taufeni Taufik }{ }^{2} \text {, Julita Julita }}^{3}$ \\ ${ }^{123}$ Program Studi Akuntansi, Fakultas Ekonomi dan Bisnis, Universitas Riau, Pekanbaru \\ *Email: gebyvia.septiyani4074@student.unri.ac.id
}

\begin{tabular}{l} 
Keywords \\
\hline Government Apparatus \\
Competency, Usage Of \\
Information Technology \\
Accounting Control, \\
Reporting System, \\
Performance \\
\hline
\end{tabular}

\section{Article Information}

Received:

2020-02-22

Accepted:

2020-05-27

Available online:

2020-07-18

\begin{abstract}
The purpose of this research is to find out the influence of government apparatus competency, usage of information technology, accounting control and reporting system against the performance accountability of government agencies. The population of this research is all of OPD in Pekanbaru Government. The sample of this research are Chief of $O P D$, Chief of Subdivision of finance, and accountability compiler staff at 43 OPD of Pekanbaru City which selected by using purposive sampling method. This research is using primer data by using questionnaires. Analysis method that used in this research is doubled regression analysis. The instrument of analysis that used in this research is statistical Product and Service Solution (SPSS) Version 17.0 for windows. The results of this research indicate that: (1) the government apparatus competency influencing performance accountability of government agencies (2) the usage of information technology influencing performance accountability of government agencies (3) the accounting control influencing performance accountability of government agencies (4) the reporting system does not influence the performance accountability of government agencies.
\end{abstract}

\section{PENDAHULUAN}

Indonesia telah memasuki masa pemulihan akibat krisis ekonomi yang berkepanjangan. Seluruh pihak termasuk pemerintah mencoba mengatasi hal ini dengan melakukan reformasi di segala bidang. Salah satu usaha memulihkan kondisi ekonomi, sosial dan politik adalah dengan mengembalikan kepercayaan rakyat kepada pemerintah dengan mencoba mewujudkan suatu pemerintahan yang bersih dan berwibawa atau dikenal dengan istilah Good Governance. Kewajiban pemerintah untuk mempertanggungjawabkan kinerjanya dengan sendirinya dipenuhi dengan menyampaikan informasi yang relevan sehubungan dengan hasil dari program yang dilaksanakan kepada wakil rakyat dan juga kelompok masyarakat.

Perbaikan pemerintahan dan sistem manajemen merupakan agenda penting dalam 
reformasi birokrasi yang sedang dijalankan oleh pemerintah saat ini. Sistem manajemen pemerintahan dinantikan berpusat pada kenaikan akuntabilitas turut sekalian kenaikan kinerja yang berkiblat pada hasil (outcome). Maka pemerintah sudah memasang kebijakan untuk aplikasi sistem pertanggungjawaban yang akurat, teratur dan efektif yang disebut dengan Sistem Akuntabilitas Kinerja Instansi Pemerintah (SAKIP).

Akuntabilitas kinerja instansi pemerintah merupakan perwujudan kewajiban suatu instansi pemerintah (pusat atau daerah) yang bertujuan untuk mempertanggungjawabkan keberhasilan dan kegagalan pelaksanaan misi organisasi dalam mencapai sasaran dan tujuan organisasi. Hal ini sejalan dengan Peraturan Presiden Republik Indonesia Nomor 29 Tahun 2014 tentang Sistem Akuntabilitas Kinerja Instansi Pemerintah disebutkan bahwa akuntabilitas kinerja adalah perwujudan kewajiban suatu instansi pemerintah untuk mempertanggungjawabkan keberhasilan atau kegagalan pelaksanaan program dan kegiatan yang telah diamanatkan para pemangku kepentingan dalam rangka mencapai misi organisasi secara terukur dengan sasaran/target yang telah ditetapkan melalui laporan kinerja instansi yang disusun secara periodik.

Evaluasi akuntabilitas kinerja terhadap pemerintah provinsi dan pemerintah kabupaten/kota, dilaksanakan secara berkala oleh Kementrian Pendayagunaan Aparatur Negara dan Reformasi Birokrasi (MENPAN \& RB) melalui tiga aspek. Pertama, untuk melihat sejauh mana komitmen penerapan manajemen sektor publik yang berbasis kinerja dalam upaya peningkatan akuntabilitas kinerja instansi pemerintah. Kedua, melalui akuntabiltas kinerja instansi pemerintah, dan ketiga, memberikan saran perbaikan atau rekomendasi untuk peningkatan kinerja dan penguatan akuntabilitas instansi.

BPK telah menerbitkan Laporan Hasil Pemeriksaan atas Sistem Pengendalian Intern dengan Nomor 23.B/LHP/XVIII.PEK/05/2019 dan Laporan Hasil Pemeriksaan atas Kepatuhan Terhadap Peraturan Perundang-undangan Nomor 23.C/LHP/XVIII.PEK/05/2019. BPK menemukan kondisi yang dapat dilaporkan berkaitan dengan sistem pengendalian intern dan ketidakpatuhan pengujian kepatuhan terhadap peraturan perundang-undangan. Pokokpokok kelemahan atas Laporan Keuangan Pemerintah Kota Pekanbaru yang ditemukan BPK adalah sebagai berikut:

1. Kesalahan penganggaran belanja modal pada Dinas Perumahan Rakyat dan Kawasan Permukiman sebesar Rp3.700.959.604,00;

2. Realisasi pembayaran gaji dan tambahan penghasilan kepada pegawai negeri sipil yang tidak berhak sebesar Rp30.684.848,00; 
3. Perjalanan dinas pada dua OPD tidak sesuai kondisi senyatanya sebesar Rp318.335.495,00;

4. Kekurangan volume atas belanja modal jalan irigasi dan jaringan pada dua OPD sebesar Rp377.052.515,00.

\section{Tabel 1}

Nilai Evaluasi AKIP

\begin{tabular}{|c|c|c|c|}
\hline No & Kategori & Nilai Angka & Interpretasi \\
\hline 1 & AA & $>90-100$ & Sangat Memuaskan \\
\hline 2 & A & $>80-90$ & $\begin{array}{l}\text { Memuaskan, Memimpin perubahan, berkinerja tinggi, dan } \\
\text { sangat akuntabel. }\end{array}$ \\
\hline 3 & BB & $>70-80$ & $\begin{array}{l}\text { Sangat Baik, Akuntabel, berkinerja baik, memiliki sistem } \\
\text { manajemen kinerja yang andal. }\end{array}$ \\
\hline 4 & B & $>60-70$ & $\begin{array}{l}\text { Baik, Akuntabilitas kinerjanya sudah baik, memiliki sistem } \\
\text { yang dapat digunakan untuk manajemen kinerja, dan perlu } \\
\text { sedikit perubahan. }\end{array}$ \\
\hline 5 & $\mathrm{CC}$ & $>50-60$ & $\begin{array}{l}\text { Cukup (Memadai), Akuntabilitas kinerjanya cukup baik, taat } \\
\text { kebijakan, memiliki sistem yang dapat digunakan untuk } \\
\text { memproduksi informasi kinerja untuk pertanggung jawaban, } \\
\text { perlu banyak perbaikan tidak mendasar. }\end{array}$ \\
\hline 6 & $\mathrm{C}$ & $>30-50$ & $\begin{array}{l}\text { Kurang, Sistem dan tatanan kurang dapat diandalkan, } \\
\text { memiliki sistem untuk manajemen kinerja tapi perlu banyak } \\
\text { perbaikan minor dan perbaikan yang mendasar. }\end{array}$ \\
\hline 7 & D & $0-30$ & $\begin{array}{l}\text { Sangat Kurang, Sistem dan tatanan tidak dapat diandalkan } \\
\text { untuk penerapan manajemen kinerja, perlu banyak perbaikan, } \\
\text { sebagian perubahan yang sangat mendasar. }\end{array}$ \\
\hline
\end{tabular}

Sumber: Menpan.go.id(2018)

Setiap instansi pemerintah, baik pemerintahan pusat maupun pemerintahan daerah, diwajibkan membuat laporan Akuntabilitas Kinerja Instansi Pemerintah dan kemudian akan mendapatkan nilai hasil evaluasi. Pada Pemerintah Kota Pekanbaru sampai saat ini masih dikatakan belum mampu menyajikan Laporan Akuntabilitas Kinerja Instansi Pemerintahnya dengan predikat memuaskan. Adapun rincian penilaian Akuntabilitas Kinerja Instansi Pemerintah Kota Pekanbaru, yaitu:

Tabel 2

Penilaian Akuntabilitas Kinerja Instansi Pemerintah Kota Pekanbaru Tahun 2015-2018

\begin{tabular}{cccc}
\hline No & Tahun & Nilai & Kategori \\
\hline 1. & 2015 & 45,13 & $\mathrm{C}$ \\
2. & 2016 & 48,81 & $\mathrm{C}$ \\
3. & 2017 & 53,50 & $\mathrm{C}$ \\
4. & 2018 & 54,68 & $\mathrm{CC}$ \\
\hline
\end{tabular}

Sumber: KEMENPAN-RB diolah kembali

Dari Tabel 2, dapat disimpulkan Akuntabilitas Kinerja Instansi Pemerintah Kota Pekanbaru tahun 2018 tak cukup baik sebagai cerminan ibukota Provinsi Riau karena hanya mampu mendapat prediket CC dengan nilai 54,68 yang artinya masih perlu banyak perbaikan 
yang tidak mendasar. penilaian SAKIP pada tahun 2018 lalu menilai performa kinerja tahun 2017. Nilai ini naik sedikit dari tahun sebelumnya di mana Pemko Pekanbaru mendapat prediket $\mathrm{C}$ dengan nilai 53,50. Jika dilihat dari nilai SAKIP tahun 2017 lalu, hanya ada peningkatan sebesar 1,18 persen. Pada tahun 2016 nilai SAKIP di Pekanbaru mendapat predikat C dengan nilai 48,81 dan di tahun 2015 nilai SAKIP di Pekanbaru mendapat prediket C dengan nilai 45,13. Pekanbaru kalah dari Kabupaten Kepulauan Meranti dan Kuantan Singingi yang bisa melompat dari D ke B dalam waktu setahun.

Dalam hal ini, setiap organisasi diwajibkan mencatat dan melaporkan setiap penggunaan keuangan negara serta kesesuaiannya dengan ketentuan yang berlaku. Laporan SAKIP terdiri atas dokumen perencanaan, pengukuran, pelaporan, evaluasi dan capaian. Dalam penilaian terakhir tahun 2018 lalu, dari 43 OPD dijajaran Pemko Pekanbaru hanya 10 OPD yang meraih nilai B. Sementara sisanya $C$.

Dari tahun 2015 sampai 2018 nilai SAKIP di Pemerintah Kota Pekanbaru mengalami kenaikan tetapi kenaikan tersebut masih belum maksimal. Untuk mencapai terwujudnya akuntabilitas kinerja yang baik ada beberapa faktor yang memperngaruhinya, yaitu: Kompetensi aparatur pemerintah, pemanfaatan teknologi informasi, pengendalian akuntansi dan sistem pelaporan.

Faktor pertama adalah Kompetensi Aparatur Pemerintah. Undang-undang Nomor 13 Tahun 2003 tentang ketanagakerjaan pasal 1 ayat 10 menyatakan kompetensi adalah kemampuan kerja setiap individu yang mencakup aspek pengetahuan, keterampilan dan sikap kerja yang sesuai dengan standar yang ditetapkan. Prediksi siapa yang berkinerja baik dan kurang baik dapat diukur dari kriteria yang digunakan.

Riska (2017), melakukan penelitian tentang pengaruh kompetensi aparatur pemerintah daerah terhadap akuntabilitas kinerja instansi pada satuan kerja perangkat daerah kota Dumai, menyimpulkan bahwa kompetensi aparatur pemerintah daerah berpengaruh positif dan signifikan terhadap akuntabilitas kinerja instansi pemerintah. Begitu juga penelitian yang dilakukan oleh Hafiz (2017) tentang pengaruh kompetensi terhadap akuntabilitas kinerja instansi pemerintah pada satuan kerja perangkat daerah kabupaten Indragiri hulu, menyimpulkan bahwa kompetensi aparatur pemerintah daerah berpengaruh positif terhadap akuntabilitas kinerja instansi pemerintah. Namun dalam penelitian yang dilakukan oleh Ardianto (2014) menyimpulkan bahwa kompetensi aparatur pemerintah daerah tidak berpengaruh terhadap akuntabilitas kinerja instansi pemerintah pada satuan kerja perangkat daerah Kabupaten Kuantan Singingi.

Faktor yang kedua adalah pemanfaatan teknologi informasi. Pemanfaatan teknologi 
informasi adalah karakter atau aksi dalam memakai teknologi informasi untuk menanggulangi pekerjaan dan menaikkan kinerjanya (Wiguna, 2016). Dengan aplikasi teknologi maka instansi akan mengalami perubahan sistem pelayanan, manajemen dan pelaporan, dari tradisional ke modern. Teknologi informasi berkaitan dengan pelayanan, dikarenakan hal tersebut merupakan kualitas yang utama untuk dipertimbangkan dengan tujuan tercapainya pelayanan yang semakin efektif, cepat dan akurat.

Faktor ketiga yang membangun terbentuknya akuntabilitas kinerja instansi pemerintah adalah pengendalian akuntansi. Pengendalian akuntansi juga berfungi sebagai satu kesatuan dalam mewujudkan akuntabilitas kinerja instansi pemerintah yang baik. Pengendalian akuntansi akan membantu pemerintah bisa melaksanakan ketentuan yang kian baik, mengatur aktivitas dengan lebih efektif, bisa memperkirakan biaya dan keuntungan keberhasilan dan memutuskan alternatif terbaik dalam setiap kejadian dan masalah sehingga bisa meningkatkan kinerja. Menurut Mardiasmo (2009), peningkatan perencanaan dan pengendalian terhadap aktivitas dengan cara perbaikan sistem akuntansi sektor publik diharapkan dapat membantu meningkatkan transparansi efisiensi serta efektivitas pemerintah daerah, terutama dalam memberikan informasi dan pengungkapan atas aktivitas dan kinerja finansial pemerintah daerah dalam mewujudkan akuntabilitas kinerja instansi pemerintah.

Faktor keempat yang membangun terbentuknya akuntabilitas kinerja instansi pemerintah adalah sistem pelaporan. Sistem pelaporan kinerja merupakan refleksi kewajiban untuk melaporkan kinerja semua aktivitas dan sumber daya yang perlu dipertanggung jawabkan Sistem pelaporan diperlukan untuk memantau hasil kerja pusat pertanggungjawaban. Supaya bisa mengontrol hasil pusat pertanggung jawaban, diharapkan sebuah sistem pelaporan. Dalam laporan patut ditunjukan hasil kerja pertanggungjawabannya turut anggaran dan lebih berfungsi laporan tersebut bilamana diikuti tentang kajian sebab munculnya penyimpangan.

Dalam penelitian yang dilakukan oleh Paramitha dan Gayatri (2016) tentang pengaruh ketepatan sasaran anggaran, sistem pengendalian manajerial sektor pemerintah dan sistem pelaporan pada akuntabilitas kinerja, menyatakan bahwa sistem pelaporan berpengaruh terhadap Akuntabilitas Kinerja Instansi Pemrintah. Akan tetapi, bertolak belakang dengan hasil penelitian Setiawan (2013) yang menyatakan Sistem pelaporan tidak berpengaruh terhadap Akuntabilitas Kinerja Instansi Pemerintah.

Penelitian ini mengacu pada penelitian Wahid (2016) yang meneliti pengaruh kejelasan sasaran anggaran, pengendalian akuntansi, kompetensi aparatur pemerintah daerah, sistem pelaporan, dan ketaatan pada peraturan perundangan terhadap akuntabilitas kinerja 
instansi pemerintah pada pada satuan kerja perangkat daerah Kabupaten Agam. Perbedaan penelitian yang akan dilakukan dengan penelitian sebelumnya yaitu peneliti menggunakan variabel independennya yaitu variabel pemanfaatan teknologi informasi, dikarenakan sekarang semakin meningkatnya tekhnologi informasi khususnya bidang akuntansi agar dapat meningkatkan akuntabilitas kinerja instansi pemerintah, hal ini didukung dengan penelitian sebelumnya yaitu Soleman et al (2019) serta objek penelitian ini adalah organisasi perangkat daerah pemerintah Kota Pekanbaru.

Berdasarkan latar belakang masalah yang telah dipaparkan di atas penelitian ini bertujuan untuk menganalisis "Pengaruh Kompetensi Aparatur Pemerintah, Pemanfaatan Teknologi Infromasi, Pengendalian Akuntansi Dan Sistem Pelaporan Terhadap Akuntabilitas Kinerja Instansi Pemerintah (Studi Empiris Pada OPD Pemerintah Kota Pekanbaru).”

\section{PENGEMBANGAN HIPOTESIS}

\section{Pengaruh Kompetensi Aparatur Pemerintah terhadap Akuntabilitas Kinerja Instansi Pemerintah}

Kompetensi aparatur pemerintah memungkinkan untuk tercapainya suatu akuntabiltas kinerja instansi pemerintah yang efektif. Sesuai dengan prinsip pedoman penyusunan pelaporan akuntabilitas kinerja instansi pemerintah yang kedua yaitu berdasarkan sistem yang bisa mempertanggungjawabkan aplikasi sumber daya secara terus menerus dengan peraturan perundang-undangan yang berlaku. Ini berarti sumber daya yang digunakan harus benar-benar konsisten dan berkompeten dibidangya alam pelaksanaan akuntabilitas kinerja instansi pemerintah yang efektif. Karena kompetensi akan mempengaruhi akuntabilitas kinerja pemerintahan. Kesuksesan pelaksanaan pekerjaan pemerintahan umum, pembangunan dan kemasyarakatan akan dapat tercapai dengan baik apabila adanya dukungan pengelola sumber daya manusia, peralatan/sarana dan prasarana serta biaya atau anggaran serta dukungan tugastugas umum lainnya yang dapat memperlancar pelaksanaan tugas pokok dan fungsi kelembagaan pemerintah daerah. Sehingga, terwujud pertanggungjawaban yang memadai atas akuntabilitas kinerja instansi publik.

Pernyataan ini didukung oleh beberapa hasil penelitian diantaranya, Hafiz (2017) menyimpulkan bahwa kompetensi pegawai berpengaruh positif dan signifikan terhadap akuntabilitas kinerja instansi pemerintah kabupaten Kampar. Begitu juga dengan Mauliziska (2015) yang meneliti pengaruh kompetensi aparatur pemerintah daerah terhadap AKIP menyimpulkan bahwa kompetensi aparatur pemerintah daerah memiliki pengaruh yang positif terhadap AKIP. Berdasarkan uraian tersebut, maka dapat dirumuskan hipotesis: 


\section{$\mathrm{H}_{1}$ : Kompetensi Aparatur Pemerintah berpengaruh terhadap Akuntabilitas Kinerja Instansi Pemerintah.}

\section{Pengaruh Pemanfaatan Teknologi Informasi Terhadap Akuntabilitas Kinerja Instansi Pemerintah}

Teknologi informasi dapat menyajikan informasi dalam bentuk yang berguna, dapat digunakan untuk mengirim informasi ke orang lain atau ke lokasi lain. Teknologi informasi mengintegrasikan data dari berbagai bagian dan mempercepat penyajian data yang dibutuhkan untuk pengambilan keputusan. Dengan memanfaatkan teknologi informasi akan mendorong terjadinya peningkatan pelayanan kepada publik.

Pemanfaatan teknologi informasi menurut Razi (2017) merupakan faedah yang diminta sebab penggunan sistem informasi dalam melakukan pekerjaannya atau karakter dalam memakai teknologi saat melancarkan pekerjaan. Salah satu manfaat diharapkan seperti peningkatan kinerja yang merupakan bagian dari akuntabilitas kinerja instansi pemerintah. Setiawan (2005) menyarankan agar konsep pemanfaatan teknologi berkaitan dengan dua hal: menggunakan atau tidak menggunakan teknologi. Pemanfaatan teknologi informasi diukur berdasarkan ketergantungan pemakai terhadap sistem informasi yang ada untuk melaksanakan tugas dan meningkatkan kinerja.

Penelitian yang dilakukan oleh Razi (2017) menyatakan bahwa informasi teknologi sangat berperan dalam peningkatan pelayanan disektor publik. Soleman (2019) juga menyimpulkan bahwa pemanfaatan teknologi informasi berpengaruh terhadap kinerja instansi pemerintah. Berdasarkan uraian tersebut, maka dapat dirumuskan hipotesis:

\section{$\mathrm{H}_{2}$ : Pemanfaatan Teknologi Informasi berpengaruh terhadap Akuntabilitas Kinerja Instansi Pemerintah.}

\section{Pengaruh Pengendalian Akuntansi terhadap Akuntabilitas Kinerja Instansi Pemerintah}

Undang-undang No. 23 tahun 2014 tentang Pemerintahan Daerah dan Undang-undang No. 33 tahun 2004 tentang perimbangan keuangan antara Pemerintah Pusat dan Pemerintah Daerah mengharuskan pemerintah memenuhi akuntabilitas dengan memperhatikan beberapa hal, antara lain: anggaran, pengendalian akuntansi dam sistem pelaporan.

Instansi pemerintah dapat mengontrol seluruh aktivitas dan semua tanggung jawab melalui penerapan pengendalian akuntansi. Hal ini juga dapat menjadi penilai baik buruknya kegiatan yang telah dilakukan pemerintah, apakah kegiatan yang dilakukan ini telah sesuai, apakah biaya yang dikeluarkan efisien mungkin atau bahkan malah mengeluarkan biaya 
dengan berlebihan, serta apakah pelayanan yang diberikan instansi pemerintah sudah efektif dan baik kepada masyarakat.

Pengendalian akuntansi diperlukan untuk menyusun rencana, metode, dan prosedur organisasi untuk menjaga kekayaan instansi dan reliabilitas data keuangan. Berdasarkan PP Nomor 71 Tahun 2010, maka laporan keuangan pemerintah sudah menggunakan pengendalian akuntansi. Pengendalian akuntansi adalah langkah dan dokumentansi yang terkait untuk mengamankan aset, melaksanakan dan mencatat transaksi keuangan dan memastikan keandalan catatan keuangan (Hery, 2009). Melalui pengendalian akuntansi yang baik, akan tersusun pelaksanaan kinerja keuangan dengan baik sehingga memudahkan proses pengambilan keputusan.

Dalam penelitian yang dilakukan oleh Herawaty (2011) menyatakan bahwa pengendalian akuntansi berpengaruh terhadap akuntabilitas kinerja instansi pemerintah. Hal ini menunjukan bahwa semakin baik pengendalian akuntansi yang dilakukan pemerintah maka semakin baik tingkat ekonomis, efesien yang dilakukan pemerintah kepada masyarakat. Berdasarkan penjelasan tersebut maka dapat dirumuskan hipotesis :

\section{H3: Pengendalian Akuntansi berpengaruh terhadap Akuntabilitas Kinerja Instansi Pemerintah.}

\section{Pengaruh Sistem Pelaporan terhadap Akuntanbilitas Kinerja Instansi Pemerintah}

Sistem pelaporan yang baik diperlukan agar dapat memantau dan mengendalikan kinerja manajerial dalam mengimplementasikan anggaran yang telah ditetapkan. Laporan umpan balik (feedback) diperlukan untuk mengukur aktivitas aktivitas yang dilaksanakan dalam rangka meningkatkan kinerja dan akuntabilitas pada pelaksanan suatu rencana atau waktu mengimplementasikan suat anggaran, sehingga manajeman dapat mengetahui hasil dari pelaksanaan rencana atau pencapaian sasaran anggaran yang ditetapkan. Pemerintah daerah selaku pengelola dana publik harus mampu menyediakan informasi keuangan yang diperlukan secara akurat, relevan, tepat waktu, konsisten dan dapat dipercaya. Suhaesti, Hardi dan Al Azhar (2016) mengatakan bahwa terdapat hubungan dan pengaruh yang kuat antara sistem pelaporan dengan AKIP, hal ini memberikan gambaran bahwa semakin cepat sistem pelaporan maka semakin tinggi akuntabilitas kinerja pemerintah dan sebaliknya semakin rendah sistem pelaporan maka akan semakin rendah akuntabilitas kinerja instansi pemerintah.

Dalam penelitian yang dilakukan Wahyuni (2014) menyatakan bahwa sistem pelaporan berpengaruh terhadap akuntabilitas kinerja instansi pemerintah karena sistem pelaporan yang baik dapat memantau dan mengendalikan kinerja aparat dalam 
mengimplementasikan anggaran yang telah ditetapkan. Demikian pula dalam penelitian Herawaty (2011) menyatakan bahwa sistem pelaporan berpengaruh terhadap akuntabilitas kinerja instansi pemerintah. Semakin baik tingkat pertanggungjawaban pemerintah kepada publik dalam menyajikan laporan keuangan maka akuntabilitas kinerja instansi pemerintah kian baik kedepannya. Berdasarkan penelitian tersebut maka dapat dirumuskan hipotesis :

$\mathrm{H}_{4}$ : Sistem Pelaporan berpengaruh terhadap Akuntabilitas Kinerja Instansi Pemerintah.

\section{METODE PENELITIAN}

\section{Lokasi Penelitian}

Lokasi penelitian ini dilakukan di Pemerintah Kota Pekanbaru yang merupakan Ibukota Provinsi Riau. Tepatnya di Organisasi Perangkat Daerah (OPD) yang ada di Pemerintah Kota Pekanbaru. Sedangkan waktu penelitian dilakukan di tahun 2019 sampai dengan selesai.

\section{Populasi dan Sampel}

Populasi dalam penelitian ini adalah Organisasi Perangkat Daerah di Kabupaten Bengkalis yang berjumlah 43 OPD. Adapun teknik pengambilan sampel dalam penelitian ini adalah menggunakan sampling jenuh atau sensus yaitu teknik pengambilan sampel dimana semua anggota populasi dijadikan sebagai sampel. Setiap OPD diambil 3 responden, yaitu: Kepala OPD, Kepala Sub Bagian Keuangan atau perwakilan dari dinas tersebut (Bendahara/Sekretaris) dan Staff Penyusun Akuntabilitas Kinerja Instansi Pemerintah.

\section{Jenis Sumber Data}

Data yang digunakan dalam penelitian ini adalah data primer. Data primer merupakan data yang di peroleh secara langsung dari sumber penelitian yakni dari sumber asli (tidak melalui perantara) yang secara khusus dikumpulkan oleh peneliti untuk menjawab pertanyaan penelitian (Indriantoro, 2001). Data primer diterima melalui menyebarkan kuisioner langsung kepada Kepala OPD, Kepala Sub Bagian Keuangan atau Perwakilan dari dinas tersebut (Bendahara/Sekretaris) dan staff penyusun Akuntabilitas Kinerja Instansi Pemerintah pada 43 OPD di Pemerintah Kota Pekanbaru.

\section{Teknik Pengumpulan Data}

Metode pengumpulan data dalam penelitian ini menggunakan kuisioner yang pertanyaanpertanyaan dibagi menjadi beberapa bagian dan merupakan gabungan dari beberapa dari beberapa dari penelitian terdahulu. 


\section{Metode Analisis Data}

Penelitian ini mempunyai empat hipotesis yang diuji dengan mengaplikasikan software SPSS (Statistical Product and Service Solution). Untuk menguji hipotesis 1, hipotesis 2, hipotesis 3 dan hipotesis 4 digunakan model analisis regresi berganda dalam penelitian ini dapat dirumuskan sebagai berikut :

$$
\mathrm{Y}=\alpha+\beta_{1} \mathrm{X}_{1}+\beta_{2} \mathrm{X}_{2}+\beta_{3} \mathrm{X}_{3}+\beta_{4} \mathrm{X}_{4}+\mathrm{e}
$$

Dimana :

$\mathrm{Y}=$ Akuntabilitas Kinerja Instansi Pemerintah

$\alpha \quad=$ Konstanta

$\beta=$ Besaran koefisien regresi dari masing-masing variable

$\mathrm{X}_{1} \quad=$ Kompetensi Aparatur Pemerintah

$\mathrm{X}_{2} \quad=$ Pemanfaatan Teknologi Informasi

$\mathrm{X}_{3} \quad=$ Pengendalian Akuntansi

$\mathrm{X}_{4} \quad=$ Sistem Pelaporan

e $\quad=$ error

\section{HASIL PENELITIAN DAN PEMBAHASAN}

\section{Hasil Statistik Deskriptif}

Tabel berikut menunjukkan hasil statistik deskriptif berdasarkan data yang diperoleh dari responden.

\section{Tabel 3}

\section{Statistik Deskriptif}

\begin{tabular}{lccccc}
\hline & N & Min & Max & Mean & Std. Deviation \\
\hline Akuntabilitas Kinerja Instansi Pemerintah (Y) & 93 & 34.00 & 50.00 & 43.23 & 3.055 \\
Kompetensi Aparatur Pemerintah (X1) & 93 & 20.00 & 30.00 & 26.19 & 2.285 \\
Pemanfaatan Teknologi Informasi (X2) & 93 & 16.00 & 25.00 & 22.08 & 1.845 \\
Pengendalian Akuntansi (X3) & 93 & 11.00 & 20.00 & 17.30 & 1.792 \\
Sistem Pelaporan (X4) & 93 & 10.00 & 20.00 & 16.43 & 2.290 \\
$\quad$ Valid N (listwise) & 93 & & & & \\
\hline
\end{tabular}

Sumber: Olah data dengan menggunakan SPSS

Dari Tabel 3 dapat dilihat statistik penelitian yakni Akuntabilitas Kinerja Instansi Pemerintah (Y) dengan nilai minimun 34, nilai maksimum sebesar 50. Nilai tengah atau mean adalah 43.23 dengan standar deviasi 3.055. Kompetensi Aparatur Pemerintah (X1) dengan nilai minimun 20, nilai maksimum sebesar 30. Nilai tengah atau mean adalah 26.19 dengan standar deviasi 2.285. Pemanfaatan Teknologi Informasi (X2) dengan nilai minimun 16, nilai 
maksimum sebesar 25. Nilai tengah atau mean adalah 22.08 dengan standar deviasi 1.845. Pengendalian Akuntansi (X3) dengan nilai minimun 11, nilai maksimum sebesar 20. Nilai tengah atau mean adalah 17.30 dengan standar deviasi 1.792. Sistem Pelaporan (X4) dengan nilai minimun 10 , nilai maksimum sebesar 20. Nilai tengah atau mean adalah 16.43 dengan standar deviasi 2.290 .

\section{Hasil Uji Hipotesis}

Berikut Tabel 4 disajikan untuk mengetahui hubungan antara variabel bebas terhadap variabel terikat dalam penelitian ini:

\section{Tabel 4}

\section{Hasil Uji t}

\begin{tabular}{|c|c|c|c|c|c|c|}
\hline & & \multicolumn{2}{|c|}{$\begin{array}{l}\text { Unstandardized } \\
\text { Coefficients }\end{array}$} & \multirow{2}{*}{$\begin{array}{c}\text { Standardized } \\
\text { Coefficients }\end{array}$} & \multirow[b]{2}{*}{$\mathrm{t}$} & \multirow[b]{2}{*}{ Sig. } \\
\hline \multicolumn{2}{|c|}{ Model } & $\mathrm{B}$ & Std. Error & & & \\
\hline \multirow[t]{5}{*}{1} & (Constant) & -10.529 & 13.678 & & -770 & .443 \\
\hline & Kompetensi Aparatur Pemerintah & 8.954 & 4.404 & .165 & 2.003 & .045 \\
\hline & Pemanfaatan Teknologi Informasi & .448 & .146 & .271 & 3.066 & .003 \\
\hline & Pengendalian Akuntansi & .631 & .151 & .370 & 4.184 & .000 \\
\hline & Sistem Pelaporan & .202 & .124 & .152 & 1.631 & .106 \\
\hline
\end{tabular}

a. Dependent Variable: Akuntabilitas Kinerja Instansi Pemerintah

Berdasarkan Tabel 4 dapat diperoleh hasil uji t dan tingkat signifikan antara variabel bebas terhadap variabel terikat dalam penelitian ini:

\section{Hasil Pengujian Hipotesis 1}

Dari Tabel 4 di atas dapat dilihat bahwa $>$ yaitu $2.003>1.986$ dan sig.t $(0.045)<$ 0,05 dengan demikian $\mathrm{H}_{0}$ ditolak dan $\mathbf{H}_{\mathbf{1}}$ diterima. Dari hasil pengujian tersebut, maka dapat disimpulkan bahwa Kompetensi Aparatur Pemerintah Berpengaruh Terhadap Akuntabilitas Kinerja Instansi Pemerintah Pemerintah Daerah Kota Pekanbaru.

Dengan diterima hipotesis ini membuktikan bahwa kompetensi aparatur pemerintah merupakan faktor penting dalam melaksanakan program dan kegiatan pemerintah untuk menghasilkan akuntabilitas kinerja instansi pemerintah yang baik. Kompetensi merupakan kemampuan dan karakteristik yang dimiliki oleh pegawai negeri sipil berupa pengetahuan, keahlian dan sikap perilaku yang diperlukan dalam melaksanakan tugas jabatannya. Kompetensi sangat membantu mewujudkan Akuntabilitas Kinerja Instansi Pemerintah yang baik sehingga dapat berguna dalam peningkatan kinerja pemerintah. Semakin tinggi kompetensi yang dimiliki maka akan cenderung meningkatkan Akuntabilitas Kinerja Instansi Pemerintah, karena kompetensi memiliki potensi untuk mempengaruhi Akuntabilitas Kinerja 
Instansi Pemerintah yaitu semakin tinggi pemahaman kepala OPD akan meningkatkan Akuntabilitas Kinerja Instansi Pemerintah.

Hasil penelitian ini sesuai dengan penelitian Imam (2016) dan Razi, Savitri, \& Al Azhar (2017) yang menyatakan bahwa kompetensi aparatur pemerintah berpengaruh terhadap akuntabilitas kinerja instansi pemerintah. Namun berbeda dengan penelitian yang dilakukan oleh Putri, Tanjung, dan Susilatri (2015) yang menyatakan bahwa kompetensi aparatur pemerintah tidak berpengaruh terhadap akuntabilitas kinerja instansi pemerintah

\section{Hasil Pengujian Hipotesis 2}

Dari Tabel 4 dapat dilihat bahwa $>$ yaitu $3.006>1.986$ dan sig.t $(0.003)<0,05$ dengan demikian $\mathrm{H}_{0}$ ditolak dan $\mathbf{H}_{2}$ diterima. Dari hasil pengujian tersebut, maka dapat disimpulkan bahwa Pemanfaatan Teknologi Informasi Berpengaruh Terhadap Akuntabilitas Kinerja Instansi Pemerintah Pemerintah Daerah Kota Pekanbaru

Keberhasilan penerapan akuntabilitas kinerja instansi pemerintah Kota Pekanbaru dapat dibantu dengan penggunaan serta pemanfaatan teknologi informasi. Dengan adanya pemanfaatan teknologi informasi, maka akan berdampak pada kinerja perusahaan. Pemanfaatan teknologi informasi yang tepat dan didukung oleh keahlian personil yang mengoperasikannya dapat meningkatkan kinerja perusahaan maupun kinerja individu yang bersangkutan.

Teknologi informasi selain sebagai komputer (hardware dan software) untuk pemrosesan dan penyimpanan informasi, juga berfungsi sebagai teknolohi komunikasi untuk penyebaran informasi. Secara umum komputerisasi telah membawa dampak yang luas dalam bidang pekerjaan akuntan dalam organisasi. Dampak utama adalah bahwa akuntan telah dapat mengalihkan aktivitasnya dari yang berisfat teknis kepada kegiatan yang berhubungan dengan proses pengambilan keputusan.

Begitu juga di pemerintahan, diharapkan aparatur di setiap OPD dapat memaksimalkan penggunaan teknologi informasi tersebut dengan maksimal, sehingga dapat menjadi lebih professional guna meningkatkan akuntabilitas kinerja instansi pemerintah dengan efektif dan efisien. Dengan memanfaatkan kemajuan teknologi informasi akan mendorong terjadinya peningkatan pelayanan kepada publik.

Hasil penelitian ini sesuai dengan penelitian yang dilakukan Danty dan Safitri (2018) yang menyatakan bahwa pemanfaatan teknologi informasi berpengaruh terhadap akuntabilitas kinerja instansi pemerintah. Namun berbeda dengan penelitian yang dilakukan oleh 
Mauliziska (2015) yang menyatakan bahwa pemanfaatan teknologi informasi tidak berpengaruh terhadap akuntabilitas kinerja instansi pemerintah.

\section{Hasil Pengujian Hipotesis 3}

Dari Tabel 4 dapat dilihat bahwa $>$ yaitu $4.184>1.986$ dan sig.t $(0.000)<0,05$ dengan demikian $\mathrm{H}_{0}$ ditotak dan $\mathbf{H}_{3}$ diterima. Dari hasil pengujian tersebut, maka dapat disimpulkan bahwa Pengendalian Akuntansi Berpengaruh Terhadap Akuntabilitas Kinerja Instansi Pemerintah Pemerintah Daerah Kota Pekanbaru.

Pengendalian akuntansi (accounting control) adalah prosedur dan dokumentasi yang terkait untuk pengamanan aset, melaksanakan dan mencatat transaksi keuangan dan memastikan keandalan catatan keuangan (Hery, 2009). Pengaplikasian sistem pengendalian akuntansi bisa memperlancar perencanaan dan kontrol aktivitas dan kinerja organisasi. Sistem akuntansi merupakan bagian yang sangat penting dalam spektrum mekanisme pengendalian keseluruhan yang digunakan untuk memotivasi, mengukur, dan memberi sanksi tindakantindakan manajer dan karyawan dari suatu organisasi.

Pengendalian akuntansi yang dilakukan pemerintah daerah berperan dalam meningkatkan akuntabilitas kinerja instansi pemerintahnya. Menurut Miah dan Goyal dalam Hilmi (2004) sistem akuntansi yang efektif merupakan prasyarat bagi kinerja yang lebih baik. Menurut Standar Profesional Akuntan Publik (2001) pengendalian intern sebagai suatu cara yang dilaksanakan oleh dewan komisaris, manajemen dan personel lain entitas yang digambar buat membagikan kepercayaan memadai atas perangkuhan tiga kriteria berikut ini: (a) keandalan pelaporan keuangan, (b) efektivitas dan efisiensi operasi, (c) kepatuhan terhadap hukum dan peraturan yang berlaku.

Semakin baik pengendalian akuntansi maka akan dapat mempermudah perencanaan dan pengawasan, hal ini juga dapat untuk pengendalian keseluruhan yang digunakan untuk memotivasi, mengukur, dan memberi sanksi tindakan-tindakan manajer dan karyawan dari suatu organisasi.

Hasil penelitian ini sejalan dengan penelitian Suhaesti, Hardi, dan Al Azhar (2016), Precelina dan Eni (2019) dan Yulianto dan Muthaher (2019) yang menyatakan bahwa pengendalian akuntansi berpengaruh terhadap akuntabilitas kinerja instansi pemerintah. Namun berbeda dengan penelitian yang dilakukan oleh Mentari, Emrinaldi, dan Hasan (2014) yang menyatakan bahwa pengendalian akuntansi tidak berpengaruh terhadap akuntabilitas kinerja instansi pemerintah. 


\section{Hasil Pengujian Hipotesis 4}

Dari Tabel 4 di atas dapat dilihat bahwa < yaitu $1.631<1.986$ dan sig.t $(0.106)>0,05$ dengan demikian $\mathbf{H}_{0}$ diterima dan $\mathrm{H}_{4}$ ditolak. Dari hasil pengujian tersebut, maka dapat disimpulkan bahwa Sistem Pelaporan Tidak Berpengaruh Terhadap Akuntabilitas Kinerja Instansi Pemerintah Pemerintah Daerah Kota Pekanbaru.

Sistem pelaporan merupakan laporan yang mendesain sistem pertanggungjawaban dari bawahan kepada atasan. Sistem pelaporan yang baik diharpkan untuk bisa megevaluasi kinerja dalam melaksanakan anggaran yang telah dipastikan sebelumnya. Pemerintah harus melepaskan informasi keuangan dan informasi lainnya yang bisa dimanfaatkan untuk pengambilan keputusan ekonomi, sosial, dan politik oleh pihak-pihak yang berkepentingan. Pemerintah harus dapat menyediakan informasi akuntansi yang akurat, relevan, tepat waktu, dapat dipercaya serta dapat dipertanggungjawabkan (LAN dan BPKP, 2000: 15).

Dari hasil penelitian ini menunjukkan bahwa meskipun di OPD Pemerintah Kota Pekanbaru telah terdapat sistem pelaporan, tetapi mereka belum memberikan gambaran atas implementasi penggunaan anggaran yang telah dipastikan. Sehingga pemerintah belum mampu menerapkan dan memanfaatkan output dari laporan tersebut dengan maksimal guna untuk pengambilan keputusan ekonomi, sosial, dan politik oleh pihak-pihak yang berkepentingan. Seharusnya apabila sistem pelaporannya itu telah maksimal, maka akan dapat meningkatkan akuntabilitas kinerja instansi pemerintah tersebut. Hal ini dikarenakan melalui sistem pelaporan yang baik instansi pemerintah dapat memantau kinerja dan melakukan perbaikan yang dilaksanakan berdasarkan output laporan yang dihasilkan.

Hasil penelitian ini sesuai dengan penelitian Yulianto dan Mutather (2019) dan Paramitha dan Gayatri (2016) yang menyatakan bahwa sistem pelaporan tidak berpengaruh terhadap akuntabilitas kinerja instansi pemerintah. Namun berbeda dengan penelitian yang dilakukan oleh Dina (2015) yang menyatakan bahwa sistem pelaporan tidak berpengaruh terhadap akuntabilitas kinerja instansi pemerintah.

\section{Analisis Koefisien Determinasi}

Analisis determinasi dapat dilihat pada Tabel 5. Berdasarkan tabel diatas, diperoleh nilai $\mathrm{R}^{2}$ (R Square) sebesar 0,503 atau $50.3 \%$. Hal ini menunjukan bahwa presentase sumbangan pengaruh variabel independen (kompetensi aparatur pemerintah, pemanfaatan teknologi informasi, pengendalian akuntansi, dan sistem pelaporan) terhadap variabel dependen (akuntabilitas kinerja instansi pemerintah) sebesar 50.3\% . atau variasi variabel independen yang digunakan dalam model (kompetensi aparatur pemerintah, pemanfaatan 
teknologi informasi, pengendalian akuntansi, dan sistem pelaporan) mampu menjelaskan 50,3\% variabel dependen. Sedangkan sebesar 49,7 \% dipengaruhi atau dijelaskan oleh variabel lain yang tidak dimasukkan dalam model penelitian ini.

\section{Tabel 5}

Hasil Uji $\mathbf{R}^{2}$

\begin{tabular}{llrrr}
\hline Model & R & R Square & $\begin{array}{c}\text { Adjusted R } \\
\text { Square }\end{array}$ & $\begin{array}{c}\text { Std. Error of the } \\
\text { Estimate }\end{array}$ \\
\hline 1 & $.709^{\mathrm{a}}$ & .503 & .480 & 2.20270 \\
\hline
\end{tabular}

a. Predictors: (Constant), Sistem Pelaporan, Pemanfaatan Teknologi Informasi, Pengendalian Akuntansi, Kompetensi Aparatur Pemerintah

b. Dependent Variable: Akuntabilitas Kinerja Instansi Pemerintah

Sumber: Olah data dengan menggunakan SPSS

\section{SIMPULAN}

Dari hasil penelitian ini dapat disimpulkan bahwa kompetensi aparatur pemerintah, pemanfaatan teknologi informasi dan pengendalian akuntansi berpengaruh terhadap akuntabilitas kinerja instansi pemerintah (studi pada OPD Pemerintah Kota Pekanbaru). Sedangkan sistem pelaporan tidak berpengaruh terhadap akuntabilitas kinerja instansi pemerintah.

Saran untuk peneliatian selanjutnya: 1) Peneliti selanjutnya dapat menambahkan variabelvariabel lainnya yang memiliki kemungkinan untuk berpengaruh terhadap Akuntabilitas Kinerja Instansi Pemerintah, seperti menambahkan variabel independen atau menggunakan variabel intervening ataupun variabel moderating untuk memperoleh hasil yang berbeda. 2) Peneliti selanjutnya dapat menambah jumlah sampel penelitian, agar hasil penelitian yang diperoleh bisa menjelaskan mengenai akuntabilitas kinerja instansi pemerintah secara umum.

Dari hasil penelitian ini dapat menjadi suatu rujukan dan masukan bagi OPD, untuk meningkatkan akuntabilitas kinerja pada setiap OPD yang ada. Dimana kompetensi aparatur, pemanfaatan tekhnologi informasi, pengendalian dan sostem pelaporan mampu meningkatkan akuntabilitas kinerja, maka diharapkan OPD akan mengalami peningkatan yang semakin baik serta dapat meningkatkan kinerjanya dalam mewujudkan visi dan misi.

\section{REFERENSI}

Ardianto. (2014). Pengaruh Penerapan Akuntabilitas Keuangan, Pemanfaatan Teknologi Informasi, Kompetensi Aparatur Pemerintah Daerah dan Ketaatan Pada Peraturan Perundagan Terhadap Akuntabilitas Kinerja Instansi Pemerintah. Jurnal Akuntansi, Vol. 2, No. 2, April 2014: 197-209.

Danty \& Safitri, W. (2018). Pengaruh Kualitas Sumber Daya Manusia dan Pemanfaatan 
Teknologi Informasi Terhadap Akuntabilitas Kinerja Instansi Pemerintah Dengan Sistem Pengendalian Internal Pemerintah Sebagai Variabel Intervening. Department of Economic Science.

Hafiz, M. (2017). Pengaruh Kompetensi Aparatur Pemerintah, Ketaatan Pada Peraturan Perundangan dan Kejelasan Sasaran Anggaran Terhadap Akuntabilitas KInerja Instansi Pemerintah dengan Komitmen Organisasi dan Kinerja Manajerial Sebagai Variable Moderating. Jurnal Ekonomi, Vol. 4, Faculty of Economics Riau University, Pekanbaru.

Herawaty, N. (2011). Pengaruh Kejelasan Sasaran Anggaran, Pengendalian Akuntansi, dan Sistem Pelaporan Terhadap Akuntabilitas Kinerja Instansi Pemerintah Daerah Kota Jambi. Jurnal Penelitian Universitas Jambi Seri Humaniora, Vol. 13, No. 2, Hal. 31 36.

Hery. (2009). Akuntansi Keuangan Menengah. Jakarta: Bumi Aksara.

Kusumaningrum, I. (2010). Pengaruh Kejelasan Sasaran Anggaran, Pengendalian Akuntansi, dan Sistem Pelaporan Terhadap Akuntabilitas Kinerja Instansi Pemerintah Provinsi Jawa Tengah. Tesis. Program Studi Magister Akuntansi Program Pasca Sarjana Universitas Dipenogoro: Jawa Tengah.

Mardiasmo. (2009). Akuntansi Sektor Publik. Yogyakarta: Andi Yogyakarta.

Mentari, C S., Emrinaldi N. D. P., \& Hasan, M. A. (2014). Pengaruh Kejelasan Sasaran Anggaran, Pengendalian Akuntansi, Penerapan Akuntansi Sektor Publik dan Ketaatan Pada Peraturan Perundangan Terhadap Akuntabilitas Kinerja Instansi Pemerintah Kota Pekanbaru. Jurnal Akuntansi.

Nugraheni, E. M., Tanjung, A.R \& Susilatri. (2015). Pengaruh Kompetensi Aparatur Pemerintah Daerah, Penerapan Akuntabilitas Keuangan, Pemanfaatan Tekhnologi Informasi, dan Ketaatan pada Peraturan Perundangan terhadap Akuntabilitas Kinerja Instansi Pemerintah (AKIP). Jurnal Online Mahasiswa, Universitas Riau.

Paramitha \& Gayatri. (2016) Pengaruh Ketepatan Sasaran Anggaran, Sistem Pengendalian Manajerial Sektor Publik dan Sistem Pelaporan Pada Akuntabilitas Kinerja. E - Jurnal Akuntansi.

Peraturan Menteri PAN \& RB No. 53 Tahun 2014 tentang petunjuk teknis perjanjian kinerja, pelaporan kinerja dan tata cara atas laporan kinerja instansi pemerintah.

Peraturan Pemerintah No. 71 Tahun 2010 tentang Standar Akuntansi Pemerintahan.

Peraturan Presiden Nomor 29 Tahun 2014 tentang Sistem Akuntabilitas Kinerja Instansi Pemerintah.

Precelina, D., \& Eni W. (2019). Pengaruh Kejelasan Sasaran Anggaran, Pengendalian Akuntansi, dan Sistem Pelaporan Terhadap Akuntabilitas Kinerja Instansi Pemerintah Kabupaten Jombang. Jurnal Mahasiswa Unesa.

Putri, E. M. N., Tanjung, A. R., \& Susilatri. (2015). Pengaruh Kompetensi Aparatur 
Pemerintah Daerah, Penerapan Akuntabilitas Keuangan, Pemanfaatan Teknologi Informasi, dan Ketaatan Pada Peraturan Perundangan terhadap Akuntabilitas Kinerja Instansi Pemerintah (AKIP). Jurnal Online Mahasiswa. Fakultas Ekonomi Universitas Riau.

Razi. R. F. Savitri, E., \& A, Al Azhar. (2017). Pengaruh Ketaatan Terhadap Peraturan Perundangan, Pemanfaatan Teknologi Informasi, Pengendalian Akuntansi dan Kompetensi Aparatur Pemerintah Daerah terhadap Akuntabilitas Kinerja Instansi Pemerintah (Studi Empiris Pada Satuan Kerja Perangkat Daerah Kabupaten Indragiri Hulu). Jurnal Online Mahasiswa, Fakultas Ekonomi Universitas Riau.

Riau.go.id. Menpan-RB Umumkan Hasil Kinerja Pemerintah Daerah https://www.riau.go.id/home/content/2017/03/21/6446-menpan-umumkan-hasilkinerja-pemerintah-daerah-di

Setiawan, E. (2013). Pengaruh Kejelasan Sasaran Anggaran, Pengendalian Akuntansi dan Sistem Pelaporan terhadap Akuntabilitas Kinerja Pemerintah (Studi Kabupaten Pelalawan). Jurnal Online Mahasiswa, Fakultas Ekonomi Universitas Riau.

Setiawan, I. (2005). Pengaruh Pengetahuan Teknologi Informasi, Pemanfaatan Teknologi Informasi, Faktor Kesesuaian Tugas-Teknologi Terhadap Kinerja Akuntan. Skripsi, Universitas Riau.

Soleman, R., Rusman S., \& Zainuddin Z. (2019). Penerapan Sistem Akuntansi Pemerintah Daerah, Kualitas Sistem Pengendalian Intern dan Pemanfaatan Teknologi Informasi Terhadap Akuntabilitas Kinerja Instansi Pemerintah. Jurnal Hibualamo Seri Ilmu Sosial dan Kependidikan.

Suhaesti, S. R., Hardi \& Al Azhar A. (2016). Pengaruh Kejelasan Sasaran Anggaran, Pengendalian Akuntansi, dan Sistem Pelaporan terhadap Akuntabilitas Kinerja Instansi Pemerintah (Studi pada Satuan Kerja Perangkat Daerah Kabupaten Bengkalis). Jurnal Online Mahasiswa.

Wahid. (2016). Pengaruh Kejelasan Sasaran Anggaran, Pengendalian Akuntansi, Kompetensi Aparatur Pemerintah, Sistem Pelaporan dan Ketaatan Pada Peraturan PerundangUndangan Terhadap Akuntabilitas Kinerja Instansi Pemerintah (Studi Empiris Pada Satuan Kerja Perangkat Daerah Kabupaten Agam). Skripsi. Universitas Riau.

Wahyuni. (2014). Pengaruh Kejelasan Sasaran Anggaran, Pengendalian Akuntansi dan Sistem Pelaporan terhadap Akuntabilitas Kinerja Instansi Pemerintah (Studi pada SKPD Kabupaten Rokan Hulu). Jurnal online Mahasiswa, Fakultas Ekonomi Universitas Riau.

Wibowo. G.B. (2016). Wako Kesal Nilai SAKIP Kota Pekanbaru Hanya Naik 1,18 Persen https://pekanbaru.tribunnews.com/2019/02/04/wako-kesal-nilai-sakip-kota-pekanbaruhanya-naik-118-persen

Wiguna, M. (2016). Pengaruh Teknologi Informasi, Pengendalian Intern, Gaya Kepemimpinan dan Good Governance Terhadap Kinerja Instansi Pemerintah. Jurnal Ekonomi. Universitas Riau. 
AKUNTABILITAS KINERJA INSTANSI PEMERINTAH : APAKAH DIPENGARUHI KOMPETENSI APARATUR,

TEKHNOLOGI INFORMASI, PENGENDALIAN AKUNTANSI, DAN SISTEM PELAPORAN?

Yulianto, A. R., \& Muntaher, O. (2019). Pengaruh Kejelasan Sasaran Anggaran, Pengendalian Akuntansi Dan Sistem Pelaporan Terhadap Akuntabilitas Kinerja Pemerintah Kabupaten Pati. Jurnal Tirtayasan Ekonomika. 